\title{
EMPLOYEE PERCEPTION OF CORPORATE SOCIAL RESPONSIBILITY IN BOSNIA AND HERZEGOVINA
}

\author{
Admir Čavalić1 \& Damir Bećirovićn
}

UDC / UDK: 174-057.16:658](497.6)

JEL classification / JEL klasifikacija: M14, L21, A13

DOI: https://doi.org/10.22598/pi-be/2018.12.1. 117

Review / Pregledni rad

Received / Primljeno: December 22, 2017 / 22. prosinca 2017.

Accepted for publishing / Prihvaćeno za tisak: June 11, 2018 / 11. lipnja 2018.

\section{Summary}

A company follows the concept of corporate social responsibility (CSR) when, in addition to its basic economic functions, it fulfills other functions to achieve greater social goals. Corporate social responsibility is an imperative in the modern world of business while in theory, it is still the subject of discussions. Nevertheless, within different theories, there is a certain consensus specifically related to the understanding of the importance of stakeholders and the existence of different levels of CSR. The main aim of this paper is to explore and analyze employee perceptions of CSR activities in Bosnia and Herzegovina. This paper will present a survey of the perception of 100 corporate representatives related to CSR, with an analysis of the influence of sociodemographic factors and job characteristics on their attitudes. In addition, the paper offers the conclusion, with a number of recommendations for improving the current state of CSR in Bosnia and Herzegovina.

Key words: Corporate social responsibility, stakeholders, companies in Bosnia and Herzegovina.

\section{INTRODUCTION}

In the last couple of decades, there has been a growing interest in corporate social responsibility (CSR). Interest in CSR is mostly expressed by representatives of academia,

\footnotetext{
1 Admir Čavalić, M.Sc., PhD Student, Faculty of Economics, University of Tuzla, Bosnia and Herzegovina, E-mail: admir.cavalic@yahoo.com

2 Damir Bećirović, M.Sc., PhD Student, International Business-Information Academy Tuzla, Bosnia and Herzegovina, E-mail: damirbeci@hotmail.com
} 
business, but also the government, media, and the general public. Being socially responsible for today's business means following the current practices that presume that companies need to focus on other direct and indirect stakeholders, in addition to focusing on its customers. By doing so, a company can be socially responsible according to different categories or levels of responsibility, from initial economic responsibilities to holistic philanthropic responsibilities.

From looking at the theoretical framework presented in this paper, it is possible to state the following hypothesis:

- The companies in Bosnia and Herzegovina follow the hierarchy of CSR represented by Carroll's pyramid of social responsibility. This means that companies primarily demonstrate economic responsibility (business, making profit, fulfillment of customers' needs). In order to understand the concept of CSR, the first part of the paper will present a theoretical framework with previous empirical studies.

- In reference to sociodemographic differences, employees have different perceptions on CSR.

The empirical part of the paper explores the attitudes of employees of companies in Bosnia and Herzegovina regarding CSR. Employees represent one of the key internal stakeholders of socially responsible activities of companies. The research shows attitudes about different categories of CSR and the key stakeholders of the company. Furthermore, this paper analyzes the influence of sociodemographic differences and job characteristics of the respondents on their attitudes towards CSR. Finally, the paper lists recommendations for action and future research in order to improve the state of CSR in Bosnia and Herzegovina.

\section{PREVIOUS EMPIRICAL STUDIES}

As regards empirical research about CSR, there have been many studies conducted around the world. While authors have discussed the legitimacy of CSR, consumers and investors have developed clear preferences for socially responsible companies. For example, empirical evidence shows that socially responsible initiatives, under certain conditions, can affect consumer intentions of purchasing products of a given company (Sankar \& Bhattacharya, 2001). Scientific research has focused on understanding company stakeholders, defining which types of CSR could be applied and the way of reconciling CSR with some established business priorities (Tafra-Vlahović, 2009). Different studies have concluded that CSR has a positive impact on the final balance, plays an important role in reputation management, leads to an increase in operational efficiency, and creates a positive atmosphere among employees. After Carroll published his pyramid of CSR, researchers have conducted a variety of empirical research to determine the practical credibility of a given model. In doing so, they have discovered that there are cultural differences when it comes to ranking some CSR categories. This will represent a basis for the critique of the model, but also an initiative to create better, improved CSR 
models, like the International Pyramid Model of CSR (Najeb, 2017). In the article "Revisiting Carroll's CSR Pyramid, An African perspective”, Visser (2006) uses Carroll's CSR model to explore the nature of CSR in Africa. He found that the hierarchy of the pyramid is as follows: economic, philanthropic, legal, and ethical. Visser also states that Carroll's model has been used in surveys in different countries in which the importance of the hierarchy of the pyramid has been found different. In addition, during the empirical research, the problem of measuring philanthropic responsibility appeared. This would be a basis for another critique of the pyramid. Hatfiled stated that Carroll's philanthropic domain is difficult to ascertain and evaluate (Zabin, 2013). Strong and Meyer (1992) have concluded that while there is strong support for the existence of economic, legal, and ethical components of CSR, it may be appropriate for the philanthropic category to be removed from Carroll's framework. Regardless of the critiques presented, a variety of research has been carried out, and for example in Tunisia, companies put the philanthropic responsibility in the first place, followed by the legal, economic and ultimately ethical responsibility (Noamene \& Elouadi, 2015).

A study from Malaysia on 457 respondents has showed the following ranking: economic, ethical, legal and philanthropic responsibility. The study emphasized that gender, race, educational level, work experience and religious factors contributed to differences in CSR perception (Dusuki \& Yusof, 2008). Another study from Malaysia has showed different results, and there the philanthropic responsibility is placed second, which is in line with Visser's research, most probably because of a strong indigenous tradition of philanthropy. Legal responsibility is placed third and ethical responsibility last (Zabin, 2013). Jamali and Mirshak (2007) have concluded that growing body of evidence suggests that in developing countries, CSR practice is focusing on philanthropic responsibilities. In Croatia, a theoretical framework for the application of the pyramid of CSR in the field of dentistry has been developed (Letica-Cerjan, 2010).

CSR is especially important from the perspective of employees who represent the key stakeholder of the company. CSR helps to attract talented individuals, it ensures that employees feel good in a company and consequently increase their commitment and the pleasure of business which leads to a better business performance (Chiang, 2010; Sjostrand, 2010; Turban \& Greening, 1997; Maignan et al., 1999; Luce et al., 2001; Cameli et al., 2017). The stated employee perceptions are related to organizational commitment. Studies have shown that ethics and social responsibility have the highest influence on employees (Peterson, 2004). Moreover, minorities and women have a higher degree of sensitivity for socially responsible activities of a company (Backhaus et al., 2002).

When it comes to Bosnia and Herzegovina, there is little research done on CSR. This is an area that is still developing, both in academia and the business world. This implies that there is an exceptional need for affirmation of the CSR concept (Delić, 2013), which should be the focus of academia, companies, government/regulators as well as the general public. Over the last few years, some studies have shown that companies in Bosnia and Herzegovina understand CSR as philanthropy, donations, well-defined employment strategy and business within the legal norms (Ćatić-Kajtazović, 2011). A consumer report has stated that most consumers do not perceive companies in Bosnia 
and Herzegovina as socially responsible companies (Mešanović, 2005). On the other hand, employees in Bosnia and Herzegovina have a positive attitude to social responsibility (Prutina \& Šehić, 2016). By examining company representatives and students, it was concluded that the general perception of CSR in Bosnia and Herzegovina is related to behavior that does not jeopardize the companies' stakeholders (Babić-Hodović et al., 2008). The results of Prime Communications research show that most company representatives (92\%) state that CSR is included in their companies' annual plans, but $87.5 \%$ of them add that their companies are still preoccupied with other priorities. Representatives think that they should devote more time to CSR activities. This research has also showed that around 58\% of companies in Bosnia and Herzegovina do present their CSR activities publicly (BH Telecom, 2016). It is important to note that there is no institutional mechanism for the development of CSR in Bosnia and Herzegovina. Nevertheless, the UN Global Agreement Network has been established. This network brings together 72 representatives of local companies and civil society organizations, with a clear mission of promoting CSR. In addition, there are a number of other initiatives aimed at developing and enhancing CSR in Bosnia and Herzegovina.

\section{THEORETICAL FRAMEWORK}

The history of CSR has been marked by a central debate on the essence of social responsibility and its main purpose, as well as a series of theories that focus on defining the term CSR. CSR became particularly interesting after World War II and during the 60 's. Market development led to more competition, which forced companies to find new ways of creating their own competitive advantage. Parallel to that, there was a sudden rise of social movements that demanded the fulfillment of various social goals. This created unprecedented pressures on governments and the business world. Different authors quickly responded and started extensive research in the field of CSR. Today, CSR is accepted as a valid paradigm and is the subject of interest of numerous institutions and groups that have been specifically designed to further research and promote CSR practices. An overview of CSR research shows that the authors and researchers initially dealt with the essence of a company's existence, answering the question of whether the basic role (purpose) of a company is narrowly economic in its nature or more social in a broader sense. In his book about CSR published in 1953, Bowen defines the social responsibility of a company as an obligation to follow policies, make decisions, and take action that is desirable within the goals and values of our society (Bowen, 2013).

Later on, the same author extends this definition, adding that CSR refers to a set of moral and personal obligations that the employer must follow, by considering his own policies, decisions, and actions in the context of the goals and values of society (Martinez et al., 2016). In the introduction to his book, Bowen emphasizes that corporate decisions and actions have a direct impact on the quality of our lives and our personalities. Corporate decisions do not only affect the company, but its stakeholders, its employees, its customers - they influence the lives and destinies of all of us (Bowen, 2013). In the early 70's ,the Committee for Economic Development (CED) used the concept of "three concentric circles" in explaining CSR - inner, intermediate and outer responsibility. 
The inner circle referred to the basic economic functions (production, jobs, economic growth, etc.), while the intermediate circle was devoted to the development of awareness about changing social values and priorities (environmental conservation, hiring, employee relations, etc.). The outer circle emphasized new responsibilities that were yet to be placed in front of the company (poverty, urban blight, etc.) (Karake-Shalhoub, 1999). Early theoretical papers about CSR are linked to Sethi's model of social responsibility, which presented three types of socially responsible behavior. These behaviors, labeled as "socially responsible performance", include (Katsoulakos \& Katsoulakos, 2006): a social obligation (obligation towards legal and market restrictions), social responsibility (responding to social norms, values, and performance expectations) and social reactivity (anticipatory and preventive adaptation to social needs). In Sethi's model, social commitment implies the fulfillment of the basic conditions of business environment, while social responsibility is related to the way companies respond to demands according to applicable social norms, values, and expectations of the public. The highest level of social activity implies social reactivity, that anticipates the future demands of the society and responds to them. Companies at the first level behavior follow legal instructions, while at the last level they get actively involved in addressing social needs. Starting from Sethi's model of social responsibility, Carroll created a model with four categories of social responsibility (Carroll, 1979): economic, legal, ethical and philanthropic responsibility. Together, these categories make the pyramid of CSR. Carroll's pyramid had a significant influence on the acceptance of the CSR movement in the business community because Carroll challenged the accepted dogma which assumed that individual entrepreneurs and companies must simultaneously be business-minded, ethical, as well as socially and ecologically responsible (Letica-Cerjan, 2010). The CSR pyramid, on the other hand, states that there is a hierarchy of different categories of CSR and that companies can enhance their own position within a category. The primary responsibility is the economic responsibility because it is fundamentally related to the company's existence (making profits). This is followed by the legal, ethical, and finally philanthropic category of social responsibility.

At the beginning of the 90's, Wood stated that CSR can be observed in the context of different roles that a company can have in a society. Thus, a company can be seen as an institution within a society, as an individual organization or as individual managers who have a moral role within the company (Wood, 1991a). Based on this, three principles of CSR can be developed: institutional, organizational and individual. Wood created the concept of social performance that, apart from these principles, also focuses on processes of social adaptation, and the results of business behavior. Social adaptation in this model relates to environmental assessment, stakeholder management, and problem management, while the results of business behavior can be social influence, social programs and social policy (Wood, 1991b). Encouraged by the processes of globalization, Quazi and O'Brien developed a multinational CSR model, adapted to new business conditions in the global marketplace. The authors criticized the existing CSR models because they were solely based on the ethnocentric experiences of Western countries. Instead, the focus of their research was directed at countries like Australia and Bangladesh. The model consists of two dimensions - the long-term CSR and the 
results of CSR activities (Quazi \& O'Brien, 2000). These are also the basic differences between CSR implementation in different cultures. The dominating model of CSR today emphasizes that CSR can be seen as economic, environmental (ecological) and social responsibility towards all stakeholders and the general public (Zheng, 2010). Economic responsibility means that a company should take into account the fulfillment of basic economic functions, that is to be financially successful and profitable in the long term. Environmental (ecological) responsibility seeks to promote the principles of ecological sustainability and responsibility towards the planet Earth. This is manifested through a series of responsive activities (waste disposal, recycling, biodiversity conservation, attitudes towards climate change and so on). Social responsibility in this model is more widely understood and refers to the overall welfare of the society. The company should help improve the welfare of the society and increase the welfare of members of a local community. Defined like this, CSR is a long-term commitment of the company, focused on tackling the effects of its own activities in the context of the economic, ecological and social dimensions of the environment. This ensures fair and long-term benefits without harm to all involved stakeholders (De Regil, 2013).

Employees are the most important stakeholders of the company, and for this reason, this paper examines the employee perception of CSR. As key stakeholders of the company, employees have clear financial and other interests in it. However, they are also naturally interested in company activities especially in activities directed at the community to which they belong. Namely, employees have two relevant roles: the role employees and the role of society members. In relation to role theories, the aim of employees is to reduce the gap between these two roles and neutralize the conflicts of the mentioned roles. Therefore, employees are interested in socially responsible activities of the company which create a positive image of the company among the general public, and which accomplish the social goals that coincide with the social interest of employees.

\section{RESEARCH METHODOLOGY}

For the purposes of testing the hypothesis, the authors have conducted the primary research by using the original questionnaire. Stratified random sampling was used for small, medium-sized and large companies in Bosnia and Herzegovina in relation to the number of employees. Authors used the population list that was created by Indirect Taxation Authority of Bosnia and Herzegovina. Representatives of one hundred companies were phone interviewed (31.25\% usable response rate). The results were analyzed in SPSS software through the use of descriptive statistics, t-test of independent samples and One-way ANOVA. Moreover, the Likert scale was used to measure the respondents' perceptions of their company's social responsibility. 


\section{RESULTS AND DISCUSSION}

Research showed that $85 \%$ of the respondents fully agreed with the claim that their company was socially responsible. As far as Carroll's CSR pyramid, $84 \%$ of the respondents fully agreed that their company had a high level of economic responsibility. Also, $83 \%$ of the respondents fully agreed regarding the legal responsibility of their company and $82 \%$ of the respondents fully agreed that their company was ethically responsible. When it came to philanthropic responsibility, 77\% of the respondents fully agreed that their company was responsible (by the standards of CSR categories). Full results were shown in Table 1.

Table 1: Respondents' perceptions of CSR

\begin{tabular}{|l|c|c|c|c|c|}
\hline \multicolumn{1}{|c|}{ Question } & $\begin{array}{c}\text { Strongly } \\
\text { agree }\end{array}$ & Agree & Neither & Disagree & $\begin{array}{c}\text { Strongly } \\
\text { disagree }\end{array}$ \\
\hline $\begin{array}{l}\text { Our company is characterized by conducting } \\
\text { socially responsible activities. }\end{array}$ & $85 \%$ & $15 \%$ & $0 \%$ & $1 \%$ & $0 \%$ \\
\hline $\begin{array}{l}\text { Our company is characterized by a high degree } \\
\text { of economic responsibility. }\end{array}$ & $86 \%$ & $14 \%$ & $0 \%$ & $0 \%$ & $0 \%$ \\
\hline $\begin{array}{l}\text { Our company is characterized by a high degree } \\
\text { of legal responsibility. }\end{array}$ & $83 \%$ & $17 \%$ & $0 \%$ & $0 \%$ & $0 \%$ \\
\hline $\begin{array}{l}\text { Our company is characterized by a high degree } \\
\text { of ethical responsibility. }\end{array}$ & $82 \%$ & $16 \%$ & $2 \%$ & $0 \%$ & $0 \%$ \\
\hline $\begin{array}{l}\text { Our company is characterized by a high degree } \\
\text { of philanthropic responsibility. }\end{array}$ & $77 \%$ & $20 \%$ & $3 \%$ & $0 \%$ & $0 \%$ \\
\hline
\end{tabular}

Source: Author's calculations

The respondents also provided answers about the importance of different stakeholders in their CSR activities. Results showed that the highest level of agreement regarding the significance of a particular stakeholder was showed for suppliers (85\%). They were followed by customers (84\%) and the government (83\%). Owners/shareholders of the company (82\%) followed.

The research results are in line with Friedman's thesis that the basic mission of an enterprise is primarily of economic nature (Friedman, 1997; Kurtić, 2009). Interestingly, respondents used the "Neither" answer only when it came to the ethical and philanthropically responsibilities of the company. This points to the complex nature of these CSR categories, but is also partly connected to the previously showed criticism of the model regarding philanthropic responsibilities. Within these categories, the dilemma may arise as to whether the company behaves in accordance with the valid morality and ethics and adequately fulfills its social role (response to social needs and expectations).

Statistical one-way ANOVA analysis was used to test the significant difference between the respondents' answers and the defined independent variable. Social-demographical data related to gender, professional qualifications, age, level of monthly paid salary, occupational record and position at the company were taken as the independent 
variable. If the observed values are less than the significance level $(\mathrm{p}=0.05)$, the null hypothesis that between mean values of dependent variables of observed groups there are no significant differences is rejected.

The Likert scale was used to measure the respondents' perceptions of their company's social responsibility. The respondents were obliged to answer 12 questions.

Table 2: ANOVA test results

\begin{tabular}{|l|c|c|c|c|c|c|c|}
\hline \multirow{2}{*}{ Question } & Gender & $\begin{array}{c}\text { Professional } \\
\text { qualification }\end{array}$ & Age & $\begin{array}{c}\text { Level of } \\
\text { salary }\end{array}$ & $\begin{array}{c}\text { Occupational } \\
\text { record }\end{array}$ & Position \\
\cline { 2 - 7 } & \multicolumn{7}{|c|}{ Sig - (2-tailed) } \\
\hline Social responsibility & 0.940 & 0.553 & 0.636 & 0.166 & 0.538 & 0.353 \\
\hline Economic responsibility & 0.365 & $\mathbf{0 , 0 0 4}$ & 0.390 & $\mathbf{0 . 0 3 0}$ & 0.299 & 0.067 \\
\hline Legal responsibility & 0.600 & 0.092 & 0.298 & 0.276 & 0.427 & 0.724 \\
\hline Ethical responsibility & 0.353 & 0.131 & 0.441 & 0.173 & 0.587 & 0.861 \\
\hline Philanthropic responsibility & 0.386 & 0.056 & 0.292 & $\mathbf{0 . 0 4 5}$ & 0.372 & 0.334 \\
\hline $\begin{array}{l}\text { Responsibility towards the owner/ } \\
\text { shareholders }\end{array}$ & 0.547 & $\mathbf{0 . 0 2 8}$ & 0.361 & 0.155 & 0.342 & 0.314 \\
\hline $\begin{array}{l}\text { Responsibility towards the } \\
\text { employees }\end{array}$ & $\mathbf{0 . 0 3 4}$ & 0.261 & 0.444 & 0.069 & 0.944 & 0.862 \\
\hline $\begin{array}{l}\text { Responsibility towards the } \\
\text { consumers }\end{array}$ & 0.270 & 0.115 & 0.508 & 0.203 & 0.279 & 0.418 \\
\hline Responsibility towards the suppliers & 0.644 & 0.494 & $\mathbf{0 . 0 3 3}$ & 0.252 & $\mathbf{0 . 0 1 6}$ & 0.882 \\
\hline $\begin{array}{l}\text { Responsibility towards the } \\
\text { government }\end{array}$ & 0.723 & 0.402 & 0.123 & 0.403 & 0.213 & 0.849 \\
\hline Responsibility towards the community & 0.711 & $\mathbf{0 . 1 4 6}$ & 0.386 & 0.092 & 0.135 & 0.980 \\
\hline $\begin{array}{l}\text { Responsibility towards the } \\
\text { environment }\end{array}$ & 0.755 & 0.234 & 0.451 & 0.201 & 0.431 & 0.957 \\
\hline
\end{tabular}

Source: Author's calculations

Table 2 shows ANOVA test results. Numbers in bold inside the table represent the statistical significance between the mean values of responses of different social-demographical groups. Results show that for most responses there is no significant difference between the observed groups. For the responses which have statistically different mean values it is not possible to draw concrete and general conclusions.

\section{CONCLUSION}

CSR is a global trend that has been developing for a couple of decades. This trend has also affected companies in Bosnia and Herzegovina. The paper presents the historical development of the concept of CSR and shows that different authors have had different visions of CSR. Regarding the development of CSR in Bosnia and Herzegovina, it can be concluded that this area is still relatively underdeveloped in relation to the practices of developed countries. Research results confirm the stated hypothesis that the com- 
panies in Bosnia and Herzegovina follow a hierarchy of social responsibility presented by Carroll's pyramid of social responsibility. The key stakeholders of CSR activities, i.e. companies in Bosnia and Herzegovina, have stated that they are primarily responsible for suppliers, and then for consumers, government bodies, and owners. The analysis of the influence of sociodemographic characteristics and job characteristics on attitudes about CSR have showed that there is mainly no statistically significant difference in the responses of different groups of respondents to the largest number of questions asked. Therefore, it can be concluded that different sociodemographic characteristics and job characteristics do not generally affect attitudes about CSR. The above findings show a rejection of the hypothesis that employees, with regard to sociodemographic differences have different perceptions of the corporate social responsibility concept.

According to the presented results, the following recommendations can be made for companies, governmental, non-governmental organizations and researchers in Bosnia and Herzegovina:

- Companies should work more towards switching to higher categories of social responsibility, such as ethical and philanthropic responsibility. Economic responsibility is the core responsibility of companies in Bosnia and Herzegovina, but in order to keep up with current world trends, it is necessary to work on enhancing other categories of CSR.

- Companies should pay attention to their own employees who are important stakeholders. In reference to the above mentioned theoretical models, being socially responsible implies taking care of employees.

- Government and NGOs should continue with campaigns promoting socially responsible practices. The long-term goal is to promote and develop a socially responsible business culture in Bosnia and Herzegovina.

- There should be more research done on the perception of CSR according to the sociodemographic and job characteristics. This would explain some results presented in this paper.

Finally, it is important to note that this paper tries to provide a basic insight into the CSR of companies in Bosnia and Herzegovina. Consequently, it should be viewed as the foundation for future research in this area.

\section{REFERENCES:}

1. Babić-Hodović, V., Mehić, E., Resić E., Kramo, A. (2008). Attitudes Research of Corporate Social Responsibility Concept in BH companies. In Proceedings of $A b$ stracts ICES 2008 Sarajevo, „Transitional Challenges of EU Integration and Globalization“. Sarajevo: Faculty of Economics Sarajevo, pp. 150-151.

2. Backhaus K.B., Stone B.A., Heiner K. (2002). Exploring the Relationship Between Corporate Social Performance and Employer Attractiveness, Business \& Society. 40 (3), pp. $292-318$. 
3. Noamene, B. T., Elouadi, S. (2015). The Pyramid of Corporate Social Responsibility (CSR): An Empirical Examination in the Tunisian Context. International Bussines Research. 8 (10), pp. 117-125.

4. BH Telecom. (2016). Istraživanje Prime Communications Agency pokazalo da su kompanije u BiH većinom društveno neodgovorne, https://www.bhtelecom.ba/fileadmin/eglasnik/pdf/2.5.2.pdf, [accessed 04.03.2017]

5. Bowen, H.R. (2013). Social Responsibilities of the Businessman. Iowa city: University of Iowa Press.

6. Carmeli A., Gilat G., Waldman D.A. (2007). The role of perceived organizational performance in organizational identification, adjustment and job performance. Journal of Management Studies 44 (6), pp. 972-992.

7. Carroll, A.B. (1979). A Three-Dimensional Conceptual Model of Corporate Performance. The Academy of Management Review, Academy of Management, 4(4), pp. 497-505.

8. Ćatić-Kajtazović, E. (2011). Ekonomski i pravni okvir za implementaciju društvene odgovornosti preduzeća u Bosni i Hercegovini, Tranzicija, Časopis za ekonomiju i politiku tranzicije, 28, pp. $104-114$.

9. Chiang, C.S. (2010). How corporate social responsibility influences employee job satisfaction in the hotel industry. UNLV Theses. Dissertations, Professional Papers, and Capstones, Las Vegas: University Libraries, University of Nevada

10. De Regil, A.J. (2003). Corporate social responsibility: Still an infant discipline. Moorpark: The Jus Semper Global Alliance.

11. Delić, A. (2013). Društvena odgovornost preduzeća. PREGLED - časopis $z a$ društvena pitanja, 54 (1), pp. 233-249.

12. Dusuki, A.W., Yusof, T.F.M. (2008). The Pyramid Of Corporate Social Responsibility Model: Empirical Evidence From Malaysian Stakeholder Persepective. Malaysian Accounting Review, 7(2), pp. 29-54.

13. Friedman, M. (1997). Kapitalizam i sloboda. Novi Sad: Global Book.

14. Gray, R. (2001). Thirty years of social accounting, reporting and auditing: what (if anything) have we learnt?. Business Ethics, A European Review, 10, pp. 9-15.

15. Karake-Shalhoub, Z. (1999). Organizational Downsizing, Discrimination and Corporate Social Responsibility. London: Quorum

16. Katsoulakos, P., Katsoulakos, Y. (2006). A multi-dimensional view of corporate responsibility, Athens: Athens Univeristy of Economics and Business

17. Kurtić, A. (2009). Društvena odgovornost - novi svjetski pokret i poslovni imperativ savremenog menadžmenta. Tranzicija. 11 (23/24), pp. 90-100.

18. Letica-Cerjan, G. (2010). Piramida profesionalne i poslovne odgovornosti u hrvatskoj stomatologiji. Acta Stomatol Croat. 44(2), pp. 101-109. 
19. Luce R.A., Barber A.E., Hillman A.J. (2001). Good Deeds and Misdeeds: A Mediated Model of the Effect of Corporate Social Performance on Organizational Attractiveness. Business \& Society, 40 (4), pp. 397 - 415.

20. Maignan I., Ferrell O.C., Hult T.M. (1999). Corporate Citizenship: Cultural Antecedents and Business Benefits. Journal of the Academy of Marketing Science. 27 (4), pp. 455-469.

21. Martinez, J.B, Fernandez, M.L., Fernandez, P.M.R. (2016). Corporate social responsibility: Evolution through institutional and stakeholder perspectives. European Journal of Management and Business Economics, 25, pp. 8 - 14.

22. Mešanović, E. (2005). Corporate Social Responsibility: Leading aspects of CSR concept in Bosnia and Herzegovina. https://www.scribd.com/document/36973962/MESANOVIC-Corporate-Social-Responsibility-BiH-2005 [accessed 10.07.2017].

23. Najeb, M. (2017). How to win the battle of ideas in corporate social responsibility: the International Pyramid Model of CSR. International Journal of Corporate Social Responsibility. 2 (4)

24. Peterson, D.K. (2004). The Relationship Between Perceptions of Corporate Citizenship and Organizational Commitment. Business \& Society, 40 (3), pp. 296-319.

25. Prutina, Ž., Šehić, Dž. (2016). Employees’ perceptions of corporate social responsibility: A case study of award recipient. Ekonomska misao i praksa, 1, pp. 239 - 260.

26. Quazi, A.M., O’Brien, D. (2000). An Empirical Test of a Cross-national Model of Corporate Social Responsibility. Journal of Business Ethics, 25 (1), pp. 33-51.

27. Sankar, S., Bhattacharya, C.B. (2001). Does Doing Good Always Lead to Doing Better? Consumer Reactions to Corporate Social Responsibility. Journal of Marketing Research, 38 (2), pp. 225-243.

28. Sjostrand, N. (2010). Do Companies Attract Quality Work Force Through CSR Experience of Two Swedish MNCs. master thesis. Lulea University of Technology

29. Tafra-Vlahović, M. (2009). Conceptual Frame of Corporate Social Responsibility. MediAnali: međunarodni znanstveni časopis za pitanja medija, novinarstva, masovnog komuniciranja i odnosa s javnostima, 3 (5), pp. 163-184.

30. Tan, G.Y.W., Komoran, R.V. (2006). Perceptions of Corporate Social Responsibility: An Empirical Study in Singapore. In International Conference on Advances in Management. Lisbon: IARIA, pp. 1-14.

31. Turban, D.B., Greening, D.W. (1997). Corporate Social Performance and Organizational Attractiveness to Prospective Employees. The Academy of Management Journal 40(3), pp. 658-672.

32. Visser, W. (2006). Revisiting Carroll's CSR Pyramid, An African perspective. In Corporate Citizenship in Developing Countries. Mahad, H. Frederiksberg: Copenhagen Business School. 
33. Wood, D. J. (1991a). Corporate Social Performance Revisited. The Academy of Management Review, 16(4), pp. 691-718.

34. Wood, D. J. (1991b). Toward Improving Corporate Social Performance. Business Horizons, 34(4), pp. 66 - 73.

35. Zabin, I. (2013). An Investigation on Practicing Carroll's Pyramid in Bangladesh. Global Journal of Management and Business Research Administration and Management. 13 (10)

36. Zheng, D. (2010). The Impact of Employees' Perception of Corporate Social Responsibility on Job Attitudes and Behaviors: A Study in China. https://www.researchgate. net/publication/254661756_The_Impact_of_Employees'Perception_of_Corporate_Social_Responsibility_on_Job_Attitudes_and_Behaviors_A_Study_in_China [accessed 15.03.2017]. 


\title{
PERCEPCIJA DRUŠTVENE ODGOVORNOSTI OD STRANE ZAPOSLENIKA PODUZEĆA U BOSNI I HERCEGOVINI
}

\author{
Admir Čavalić ${ }^{3} \&$ Damir Bećirović ${ }^{4}$
}

\section{Sažetak}

Kompanija slijedi koncept društveno odgovornog poslovanja kada i pored svojih osnovnih ekonomskih funkcija, ispunjava i druge funkcije u cilju postizanja širih društvenih ciljeva. Korporativna društvena odgovornost predstavlja imperativ u modernom svijetu poslovanja dok je u teoriji još uvijek predmet rasprave. Ipak, unutar različitih teorija, postoji određen konsenzus i to vezano za razumijevanje važnosti dionika kompanije $i$ postojanja različitih nivoa socijalno društvenih aktivnosti. Glavni cilj ovog rada je istražiti i analizirati percepcije zaposlenika prema društveno odgovornim aktivnostima u Bosni i Hercegovini. Rad će prikazati istraživanje percepcija 100 predstavnika kompanija o društvenoj odgovornosti, uz analizu utjecaja sociodemografskih faktora i karakteristika posla na njihove stavove. Također, ovaj rad, kao dodatak zaključku, navodi preporuke za poboljšanje trenutnog stanja korporativne društvene odgovornosti u Bosni i Hercegovini.

Ključne riječi: Korporativna društvena odgovornost, dionici, kompanije u Bosni i Hercegovini.

JEL klasifikacija: M14, L21, A13

\footnotetext{
3 Admir Čavalić, mr.sc., doktorand, Ekonomski fakultet, Univerzitet u Tuzli, Bosna i Hercegovina, E-mail: admir.cavalic@yahoo.com

${ }^{4}$ Damir Bećirović, mr.sc., doktorand, Internacionalna poslovno-informacijska akademija Tuzla, Bosna i Hercegovina, E-mail: damirbeci@hotmail.com
} 